\title{
Use of complementary and alternative therapies in infants under 3 months in Jordan
}

Zina Al-Alami, ${ }^{1}$ Esra'a Taybeh, ${ }^{2}$ Mervat Alsous ${ }^{3}$ and May Abu-Hakmeh ${ }^{4}$

${ }^{1}$ Department of Medical Laboratory Sciences, Faculty of Allied Medical Sciences, Al-Ahliyya Amman University, Amman, Jordan. ${ }^{2}$ Department of Applied Pharmaceutical Sciences and Clinical Pharmacy, Faculty of Pharmacy, Isra University, Amman, Jordan. ${ }^{3}$ Department of Clinical Pharmacy and Pharmacy Practice, Faculty of Pharmacy, Yarmouk University, Irbid, Jordan. ${ }^{4}$ Dr May Abu-Hakmeh Pediatric Clinic, Amman, Jordan. (Correspondence to: Zina Al-Alami: z.alalami@ammanu.edu.jo).

\begin{abstract}
Background: The use of complementary and alternative medicine in infants to maintain health and treat illnesses is popular in Jordan. No guidelines or regulations govern their use.
\end{abstract}

Aims: This study explored mothers' knowledge and use of complementary and alternative therapies for infants younger than 3 months in Jordan and their reasons for using these remedies.

Methods: This was a cross-sectional study of a convenience sample of mothers of babies born in 2015 in Jordan. Data were collected using a questionnaire posted on six Facebook groups that target mothers in Jordan. Mothers were asked about their use of several complementary and alternative therapies for different conditions.

Results: Of 1028 questionnaires received, 520 were included in the analysis. Most mothers (81.3\%) were 18-29 years old and had a university degree (78.3\%). Most knew about the use of the complementary and alternative medicines for bloating/colic but had never used them. Of the medicines used for bloating/colic, aniseed was most often used (by 70.2\% of mothers). Aniseed was also used by $60.8 \%$ of mothers to help their baby sleep and by $48.1 \%$ for constipation. The main reasons for using these remedies were availability at home $(60.4 \%)$ and social acceptability of their use (55.4\%). The main sources of information about these medicines were older female relatives (78.1\%) and social media (56.0\%).

Conclusions: The use of complementary and alternative medicines for babies is common in Jordan. Efforts are needed to increase awareness among mothers of the risks, side-effects and efficacy of complementary and alternative therapies in infants.

Keywords: complementary therapies, infants, neonates, mothers, Jordan

Citation: Al-Alami Z; Taybeh E; Alsous M; Abu-Hakmeh M. Use of complementary and alternative therapies in infants under 3 months in Jordan. East Mediterr Health J. 2021;27(1):7-15. https://doi.org/10.26719/emhj.20.092

Received: 21/05/19; accepted: 16/10/19

Copyright (C) World Health Organization (WHO) 2021. Some rights reserved. Open Access. This work is available under the CC BY-NC-SA 3.0 IGO license (https://creativecommons.org/licenses/by-nc-sa/3.o/igo).

\section{Introduction}

The use of complementary and alternative medicine for the treatment of diseases has a long tradition worldwide (1). According to the World Health Organization, traditional medicine is defined as, "the sum total of the knowledge, skill, and practices based on the theories, beliefs, and experiences indigenous to different cultures, whether explicable or not, used in the maintenance of health as well as in the prevention, diagnosis, improvement or treatment of physical and mental illness" (2) whereas complementary and alternative medicine is defined as, "A broad set of health care practices that are not part of that country's own tradition or conventional medicine and are not fully integrated into the dominant health-care system" (2). Complementary and alternative medicine may include using herbs, prayers and spiritual healing, aromatherapy, special food, massage and body movement, cupping, vitamins, relaxation techniques and acupuncture (1).

The prevalence of the use of complementary and alternative medicine in children in Europe is 52\% (3). One in every nine children in the United States of America
(USA) has been given some type of complementary and alternative therapy (4). The use of complementary and alternative medicine is considerably higher in children with special health care needs: the use of such medicine is most common in children with asthma (5), epilepsy (6), attention-deficit hyperactivity disorder (7), autism (8), cerebral palsy (9), cystic fibrosis (10), inflammatory bowel disease (11), anaemia and juvenile rheumatoid arthritis (12). Despite its wide use, complementary and alternative medicine has risks, especially as laws and regulations on its use are generally lacking (13). In addition, parents often do not report the use of complementary and alternative medicine to the paediatrician (3). As a result, research done in conventional medical settings may not have sufficiently described the use of complementary medicine in young children (14). Therefore, research on the use of complementary and alternative medicine in children in the general population using representative samples are needed.

In Jordan, the use of complementary and alternative medicine, including herbs, is popular during infancy to help treat mild and severe illnesses. Several studies 
have reported the use of complementary and alternative medicine in children in Jordan: in paediatric patients (aged more than 1 year) at a neurology clinic (15); in children with cancer $(16,17)$; by parents to manage illnesses of their children younger than 12 years (2); as traditional care practice for newborns (1-4 weeks) (18); and as traditional practice in infants in rural areas (19). To our knowledge, no studies in Jordan have looked into the use of complementary and alternative medicine in babies up to 3 months of age. The aims of this study therefore were to explore mothers' reasons for using traditional, complementary and alternative therapies for their babies in the first three months of life, and the sources of information on the use of such therapies.

\section{Methods}

\section{Study design and sample}

This was a cross-sectional study conducted in 2015 in Jordan. A convenience sample of Jordanian mothers of infants born in 2015 in Jordan was recruited. The exclusion criteria were: (i) incomplete questionnaires; (ii) questionnaires completed twice by the same mother with twin infants; and (iii) questionnaires completed by mothers whose infants were born in years other than 2015 or in a country outside Jordan.

We chose the age group $0-3$ months because babies at this early stage depend on milk as their primary source of nutrition.

\section{Data collection}

We used a questionnaire to assess different traditional, complementary and alternative medicine practices. We reviewed scientific literature and articles in local magazines and newspaper as the first step in developing the questionnaire. We posted a short survey on traditional practices/remedies used by mothers for their children on Facebook groups dedicated to motherhood and childhood in Jordan. We included all the complementary and alternative medicine products reported by the mothers who completed the survey in our questionnaire. The research committee at the school of pharmacy in Isra University, which includes professors of medicine, biology and pharmacy, reviewed the questionnaire and provided feedback. The questionnaire was developed and distributed in Arabic.

To ensure face and content validity of the questionnaire, it was also reviewed by two independent faculty members at Isra University with doctorates in clinical pharmacy. We rephrased some items for clarity based on the comments of the reviewers.

The questionnaire had four sections that explored: (i) mothers' knowledge and use of traditional remedies for colic and bloating; (ii) mothers' use of traditional practices for the treatment or prevention of other baby ailments; (iii) mothers' reasons for using these treatments; and (iv) mothers' sources of information on these complementary and alternative treatments.

The final version of the questionnaire was posted online to six Facebook groups that target mothers in Jordan with their permission: moms to be Jordan (https://www.facebook.com/groups/397387487039655/); mommy to be (https://www.facebook.com/groups/ mommytobesecretgroup); smart mama (https:// www.facebook.com/groups/481735031997763/); breastfeeding in Jordan (https://www.facebook.com/ groups/breastfeedinginjordan/); Jordanian mamaz in the United Arab Emirates (https://www.facebook.com/ groups/803574686387943/); and babies food (https://www. facebook.com/groups/babiesfood/). The questionnaire was live online for a week in January 2017 and data were collected using Survey Monkey (San Mateo (CA), USA).

\section{Statistical analysis}

We transferred data from Survey Monkey to Excel and translated them into English. We used descriptive statistics to describe the demographic characteristics of the responders, and the chi-squared test to examine differences between groups for categorical variables. We considered a P-value of less than 0.05 as statistically significant. We used SPSS, version 24 for statistical analyses.

\section{Ethical considerations}

The Scientific Committee in the Faculty of Pharmacy of Isra University (Amman, Jordan) approved the study.

The questionnaire was anonymous. Mothers were informed that their data was confidential and that the study would neither harm nor help them directly, and that the results would be a valuable addition to the field of paediatrics. Information about the participating mother's age ( $<18,18-29,30-39$ and $\geq 40$ years), educational level, city of residence and health insurance was collected for statistical analyses.

\section{Results}

\section{Response rate}

Of the 1028 submitted questionnaires, we included 520 in the analysis. We excluded questionnaires that were incompletely filled, and questionnaires filled by mothers who gave birth before or after 2015 and who gave birth outside Jordan.

The total number of newborns in Jordan in 2015 was 198018 (Jordanian statistics department, 2015) (20). A sample size of 383 provides a $95 \%$ confidence level to provide statistically meaningful data with an alpha level of 0.05 . Our final sample size (520) therefore provides $95.7 \%$ power.

\section{Characteristic of the mothers}

None of the mothers was younger than 18 or older than 40 years: 423 (81.3\%) were $18-29$ years old and 97 (18.7\%) were 30-39 years. Most of the mothers were residents of Amman (315; 60.6\%), while 64 (12.3\%) were from Zarqa and $52(10.0 \%)$ were from Irbid. Only 41 (7.9\%) mothers had less than secondary school education, while 366 (70.4\%) had a bachelor degree. The demographic characteristics of the mothers are shown in Table 1. 


\begin{tabular}{|c|c|}
\hline Characteristic & $\begin{array}{c}\text { No. }(\%) \\
(n=520)\end{array}$ \\
\hline \multicolumn{2}{|l|}{ Mother's age (years) } \\
\hline $18-29$ & $423(81.3)$ \\
\hline $30-39$ & $97(18.7)$ \\
\hline \multicolumn{2}{|l|}{ Residence } \\
\hline Amman & $315(60.6)$ \\
\hline Zarqa & $64(12.3)$ \\
\hline Irbid & $52(10.0)$ \\
\hline Balqaa & $23(4.4)$ \\
\hline Aqaba & $13(2.5)$ \\
\hline Other in Jordan & $30(5.8)$ \\
\hline Outside Jordan & $23(4.4)$ \\
\hline \multicolumn{2}{|l|}{ Medical insurance } \\
\hline Not insured & $128(24.6)$ \\
\hline Governmental insurance & $150(28.8)$ \\
\hline Through UNRWA & $15(2.9)$ \\
\hline Private insurance & $200(38.5)$ \\
\hline Two types of insurance & $27(5.2)$ \\
\hline \multicolumn{2}{|l|}{ Educational level } \\
\hline Secondary school or less & $41(7.9)$ \\
\hline Professional (skills) training only & $5(1.0)$ \\
\hline Diploma in medical field & $20(3.8)$ \\
\hline Diploma in non-medical field & $47(9.0)$ \\
\hline Bachelor degree in medical field & $82(15.8)$ \\
\hline Bachelor degree in non-medical field & $284(54.6)$ \\
\hline Postgraduate degree in medical field & $32(6.2)$ \\
\hline Postgraduate degree in non-medical field & $9(1.7)$ \\
\hline
\end{tabular}

UNRWA: United Nations Relief and Works Agency for Palestine Refugees in the Near East.

\section{Baby colic and bloating}

Table 2 shows the mothers' use of complementary and alternative medicine for treating their babies' colic or bloating. Most participants were aware of the reported use of these complementary and alternative medicine for baby colic and bloating but had never used them. Of the complementary and alternative medicines used for bloating and colic, the most frequently used one was aniseed (used by $70.2 \%$ ), cumin $(36.7 \%$ ), chamomile $(34.8 \%)$, sage $(27.3 \%)$, mint (26.2\%) and fennel (26.0\%).

About half of the mothers were not aware of teucrium. Most of the mothers were familiar with mint $(69.8 \%)$, sage (69.4\%), fennel (64.0\%) and cumin (59.6\%) even though they had never used them to treat colic or bloating (Table 2).

\section{Minor diseases in infants}

Complementary and alternative medicines used to treat some conditions in babies in the first 3 months of their lives are shown in Table 3. Most mother did not use any complementary or alternative medicines to treat baby jaundice, nappy rash, cough, eye problems, diarrhoea, or colds. However, almost a quarter of the mothers used a mix of rock candy with water $(24.4 \%)$ or date extract $(22.7 \%)$ to treat jaundice. Just over a quarter $(26.5 \%)$ of the mothers used starch mixed with grease or oil to treat nappy rash. Two fifths of the mothers massaged their babies with sesame oil to treat a cough and $29.4 \%$ used bitter tea to treat eye inflammation. As regards other conditions, over half the mothers $(60.8 \%)$ used aniseed as a sedative to help the baby sleep for a long time and $48.1 \%$ used this plant to treat constipation. Almost all the mothers (90.4\%) used olive oil for body massaging for overall well-being while $2.7 \%$ used castor oil for massage.

\begin{tabular}{|c|c|c|c|c|c|c|}
\hline $\begin{array}{l}\text { Treatment used: English } \\
\text { name (scientific name) }\end{array}$ & $\begin{array}{l}\text { Used it for } \\
\text { colic, No. (\%) }\end{array}$ & $\begin{array}{l}\text { Used it for } \\
\text { bloating, No. } \\
(\%)\end{array}$ & $\begin{array}{c}\text { Used it for } \\
\text { colic and } \\
\text { bloating, No. } \\
\text { (\%) }\end{array}$ & $\begin{array}{l}\text { Know about } \\
\text { it but never } \\
\text { used it, No. } \\
\text { (\%) }\end{array}$ & $\begin{array}{l}\text { Didn't know } \\
\text { that it was } \\
\text { used for colic } \\
\text { and bloating, } \\
\text { No. (\%) }\end{array}$ & $\begin{array}{c}\text { Don't know } \\
\text { this product, } \\
\text { No. (\%) }\end{array}$ \\
\hline Anise (Pimpinella anisum) & $28(5.4)$ & $196(37.7)$ & $141(27.1)$ & $149(28.7)$ & $5(1.0)$ & $1(0.2)$ \\
\hline $\begin{array}{l}\text { Chamomile (Matricaria } \\
\text { chamomilla) }\end{array}$ & $18(3.5)$ & $56(10.8)$ & $107(20.6)$ & $316(60.8)$ & $21(4.0)$ & $2(0.4)$ \\
\hline $\begin{array}{l}\text { Wall germander (Teucrium } \\
\text { chamaedrys) }\end{array}$ & $16(3.1)$ & $0(0.0)$ & $3(0.6)$ & $234(45.0)$ & $26(5.0)$ & $241(46.3)$ \\
\hline Thyme (Thymus vulgaris) & $3(0.6)$ & $1(0.2)$ & $7(1.3)$ & $439(84.4)$ & $63(12.1)$ & $7(1.3)$ \\
\hline Fennel (Foeniculum vulgare) & $3(0.6)$ & $94(18.1)$ & $38(7.3)$ & $333(64.0)$ & $36(6.9)$ & $16(3.1)$ \\
\hline Caraway (Carum carvi) & $2(0.4)$ & $25(4.8)$ & $15(2.9)$ & $396(76.2)$ & $63(12.1)$ & $19(3.7)$ \\
\hline Cumin (Cuminum cyminum) & $4(0.8)$ & $145(27.9)$ & $42(8.1)$ & $310(59.6)$ & $18(3.5)$ & $1(0.1)$ \\
\hline $\begin{array}{l}\text { Mahaleb or St Lucie cherry } \\
\text { (Prunus mahaleb) }\end{array}$ & $0(0.0)$ & $11(2.1)$ & $7(1.3)$ & $345(66.3)$ & $69(13.3)$ & $88(16.9)$ \\
\hline Sage (Salvia officinalis) & $92(17.7)$ & $18(3.5)$ & $32(6.2)$ & $361(69.4)$ & $16(3.1)$ & $1(0.2)$ \\
\hline Mint (Mentha spicata) & $29(5.6)$ & $63(12.1)$ & $44(8.5)$ & $363(69.8)$ & $20(3.8)$ & $1(0.2)$ \\
\hline Orange blossom water & $17(3.3)$ & $67(12.9)$ & $34(6.5)$ & 354 (68.1) & $43(8.3)$ & $5(1.0)$ \\
\hline
\end{tabular}




\section{Sources of information}

The participants' mothers and mothers-in-law were the main sources of information about complementary and alternative medicine $(78.1 \%)$, while $56.0 \%$ depended on information published on social media (Figure 1). Participants with a lower education level (less than a bachelor degree) versus those with a higher education level (bachelor degree or higher) tended to ask either a relative (64/113 (56.6\%) versus $163 / 407$ (40.1\%); $P=0.002)$, or their doctor or pharmacist or someone working in health care $(59 / 113$ (52.2\%) versus $140 / 407$ (34.4\%); $P=0.001)$. Younger mothers were more likely to be influenced by social media in their decision to use complementary and alternative medicine: 252 (59.6\%) mothers aged 18-29 years versus 39 (40.2\%) mothers aged 30 years or more $(P=0.001)$.

\section{Benefits of complementary and alternative medicine}

Most mothers $(419 / 520 ; 80.6 \%)$ reported that they had used complementary and alternative medicine to treat themselves. About half of the mothers $(249 ; 47.9 \%)$ believed that complementary and alternative medicines could harm their infant, while $(411 ; 79.0 \%)$ believed that their infants had benefitted from complementary and alternative medicines. These beliefs were associated with a higher education level - more mothers with a bachelor or postgraduate degree believed that complementary and alternative medicines could have harmful effects: 218/407 (53.6\%) mothers with a bachelor or postgraduate degree versus $38 / 113(33.6 \%)$ of those with less than a bachelor degree $(P<0.001)$. More educated mothers also thought that their child had not benefitted from these medicines: 93/407 (22.8\%) mothers with bachelor or postgraduate degree versus $16 / 113(14.2 \%)$ mothers with less than a bachelor degree $(P=0.045)$. Only $17 / 520(3.3 \%)$ mothers reported that their infants had experienced side-effects when using complementary and alternative medicine.

\section{Reasons for use}

The most common reasons for using complementary and alternative medicine in infants were the availability of these medicines at home $(60.4 \%)$, because these medicines are known and used in the community (55.4\%) and because conventional medicines may cause side-effects (50.0\%). The results are presented in Figure 2. The belief that complementary and alternative medicines give better results than conventional medicines and that the latter can harm their children was significantly more common in mothers of a lower education level: 59/113 (52.2\%) of mothers whose education level was less than bachelor degree versus $139 / 407$ (34.2\%) mothers with a bachelor or postgraduate degree $(P<0.001)$.

\section{Discussion}

Our study shows that mothers use complementary and alternative medicine for treatment or prevention of various baby ailments during the first 3 months of life. Chiefly, they tend to use different complementary and alternative therapies for treating their babies' colic and

\begin{tabular}{|c|c|}
\hline $\begin{array}{l}\text { Complementary and alternative medicines } \\
\text { used for: }\end{array}$ & $\begin{array}{l}\text { No. }(\%) \\
(n=520)\end{array}$ \\
\hline \multicolumn{2}{|l|}{ Treatment of jaundice } \\
\hline Mix of rock candy with grease & $14(2.7)$ \\
\hline Mix of rock candy with water & $127(24.4)$ \\
\hline Date extract & $118(22.7)$ \\
\hline Chain of garlic & $82(15.8)$ \\
\hline Full-fat cow's milk & $7(1.3)$ \\
\hline \multicolumn{2}{|l|}{ Treatment of nappy rash } \\
\hline Starch slurry & $57(11.0)$ \\
\hline Starch mixed with grease or oil & $138(26.5)$ \\
\hline Banana peels & $1(0.2)$ \\
\hline \multicolumn{2}{|l|}{ Treatment of cough } \\
\hline Drinking sesame oil & $109(21.0)$ \\
\hline Massaging sesame oil & $208(40.0)$ \\
\hline Black caraway & $13(2.5)$ \\
\hline Radish extract & $6(1.2)$ \\
\hline \multicolumn{2}{|l|}{ Treatment of eye inflammation } \\
\hline Drops of breast milk & $100(19.2)$ \\
\hline Compresses of bitter tea & $153(29.4)$ \\
\hline Honey spreads & $5(1.0)$ \\
\hline \multicolumn{2}{|l|}{ Treatment of diarrhoea } \\
\hline Starch & $56(10.8)$ \\
\hline Rice water & $128(24.6)$ \\
\hline \multicolumn{2}{|l|}{ Treatment of cold symptoms } \\
\hline Onion juice & $8(1.5)$ \\
\hline Home-made salty water as nasal drops & $39(7.5)$ \\
\hline \multicolumn{2}{|l|}{ Other practices } \\
\hline Aniseed to treat constipation & $250(48.1)$ \\
\hline a long time & $51(9.8)$ \\
\hline Aniseed to help the baby sleep for a long time & $316(60.8)$ \\
\hline Washing the baby with salted water & $151(29.0)$ \\
\hline Massaging with olive oil & $470(90.4)$ \\
\hline Massaging with castor oil & $14(2.7)$ \\
\hline
\end{tabular}

bloating problems. The use of such therapies for infantile colic is perhaps because this condition is known to have many causes and evidence is limited on an effective treatment for managing it (21).

We know that aniseed is widely used during infancy in Jordan because it soothes a crying baby by reducing colic and bloating pain. Our results showed that most mothers preferred to use aniseed for this purpose. In fact, it has been previously documented that mothers in Jordan frequently give their neonates bottles of boiled herbs containing aniseed and sage (18). In addition, in traditional Iranian medicine, fennel and aniseed were used to treat symptoms of colic (22). Aniseed has been shown to have sedative and antispasmodic properties (23). It has also been shown that the essential oil of aniseed reduces spasms of the gastrointestinal tract, and extract of aniseed increases milk production of lactating mothers and reduces the gastrointestinal problems of their infants 
Figure 1 Mothers' sources of information about complementary and alternative medicine

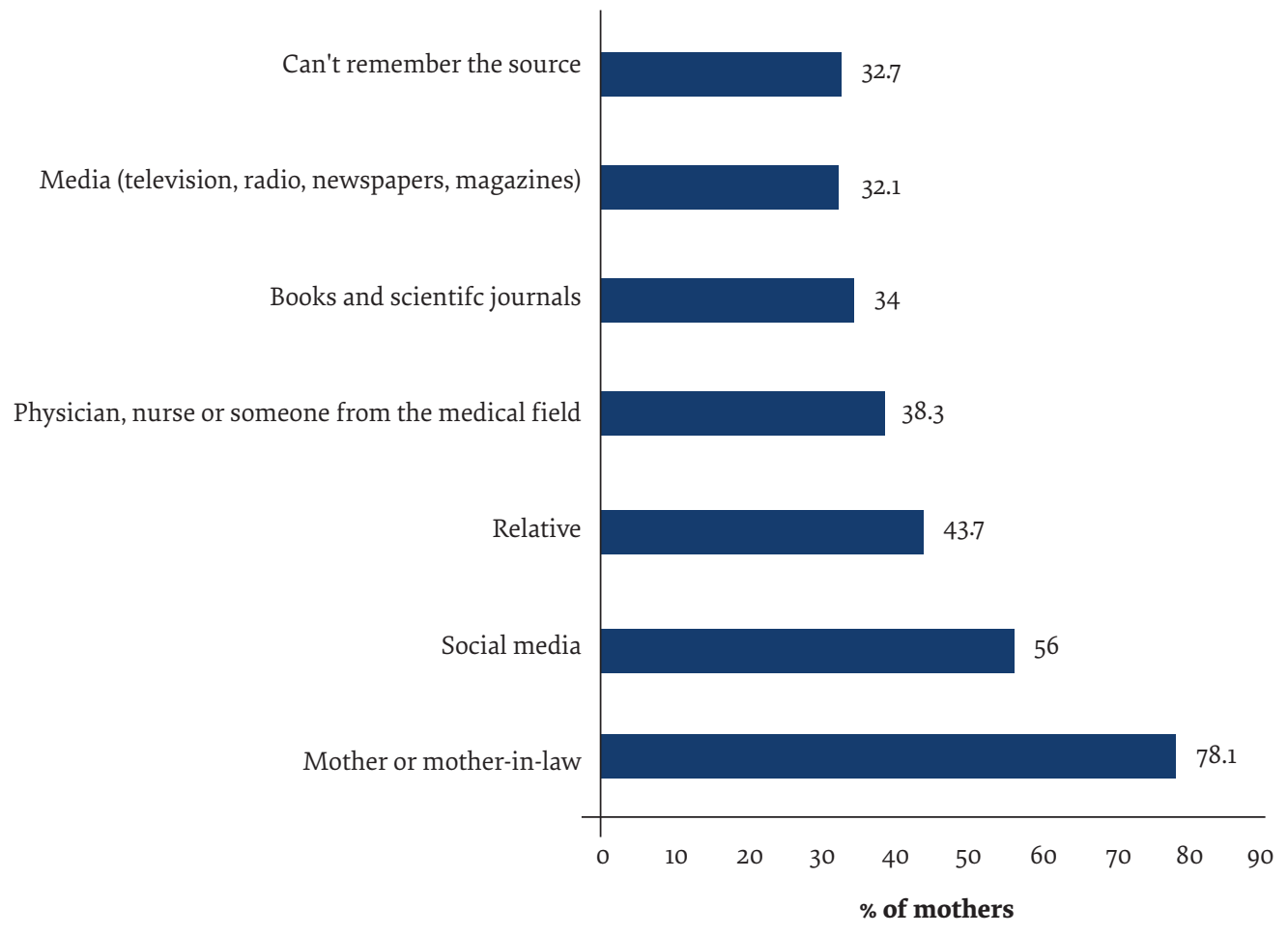

(24). Nevertheless, caution is needed while using aniseed in neonates and infants because it might have some toxic effects (25). This toxic effect is attributed to the fact that aniseed contains anethole in the essential oil which may cause neurological symptoms (26). Therefore, awareness campaigns are needed to educate the community about the possible side-effects of aniseed.

Our results also show that the other traditional colic remedy that is often used is massaging with olive oil, which has been reported to be used extensively in Jordan $(18,19)$.

Many of the common complementary and alternative medicine used traditionally were not familiar to most of our participants. Nevertheless, we know from our initial short survey on general traditional practices by mothers that these practices are used by older Jordanian generations and by some young mothers. In particular, these include massaging with olive oil and putting a necklace of garlic to treat jaundice. We believe it is important to document these practices and to conduct scientific research on the validity and rationale of their use, especially as many of them are not reported in the literature.

The average of total reading hours per year in the Jordanian population is only 50 hours, according to the 2016 Arab reading index (27). As Jordanian people rarely read, they get their information from other sources that might not be reliable. According to our results, mothers depend on relatives and social media for their information on remedies for childhood ailments. Our data is consistent with previous findings in Jordan that showed that mothers and mothers-in-law are the first source of information on questions about early infancy (18). For participants in our study, mothers, mothers-in-law and elderly contacts were the main source of information about complementary and alternative medicine. In fact, the care of a newborn baby is primarily a maternal duty in Jordan; most new mothers choose to spend at least 40 days after delivery at the home of their parents or their husband's parents, if they do not already live within an extended family. Indeed, mothers in our study who lived outside Jordan preferred to give birth in Jordan so as to spend time with their mothers after delivery.

Social media was the second most important source of information about complementary and alternative medicine. This finding might be linked to the fact that most of our participants were $18-29$ years old and lived in Amman, the capital of Jordan. According to reports of the Jordanian telecommunication regulatory commission, the percentage penetration rates of mobile telephones and Internet use in the Jordanian population in 2015 were $145 \%$ and $48.4 \%$, respectively (28). This finding suggests that some Jordanians have multiple mobile telephones and SIM cards, which makes social media highly available and accessible.

The two main reasons for the mothers gave for using complementary and alternative therapies were their availability in the house and their acceptance within society. Herbal medicine is widely used in Jordan (29), and most of the products mentioned in the questionnaire are available in all Jordanian households.

Although complementary and alternative therapies 
Figure 2 Mothers' reasons for using complementary and alternative medicine

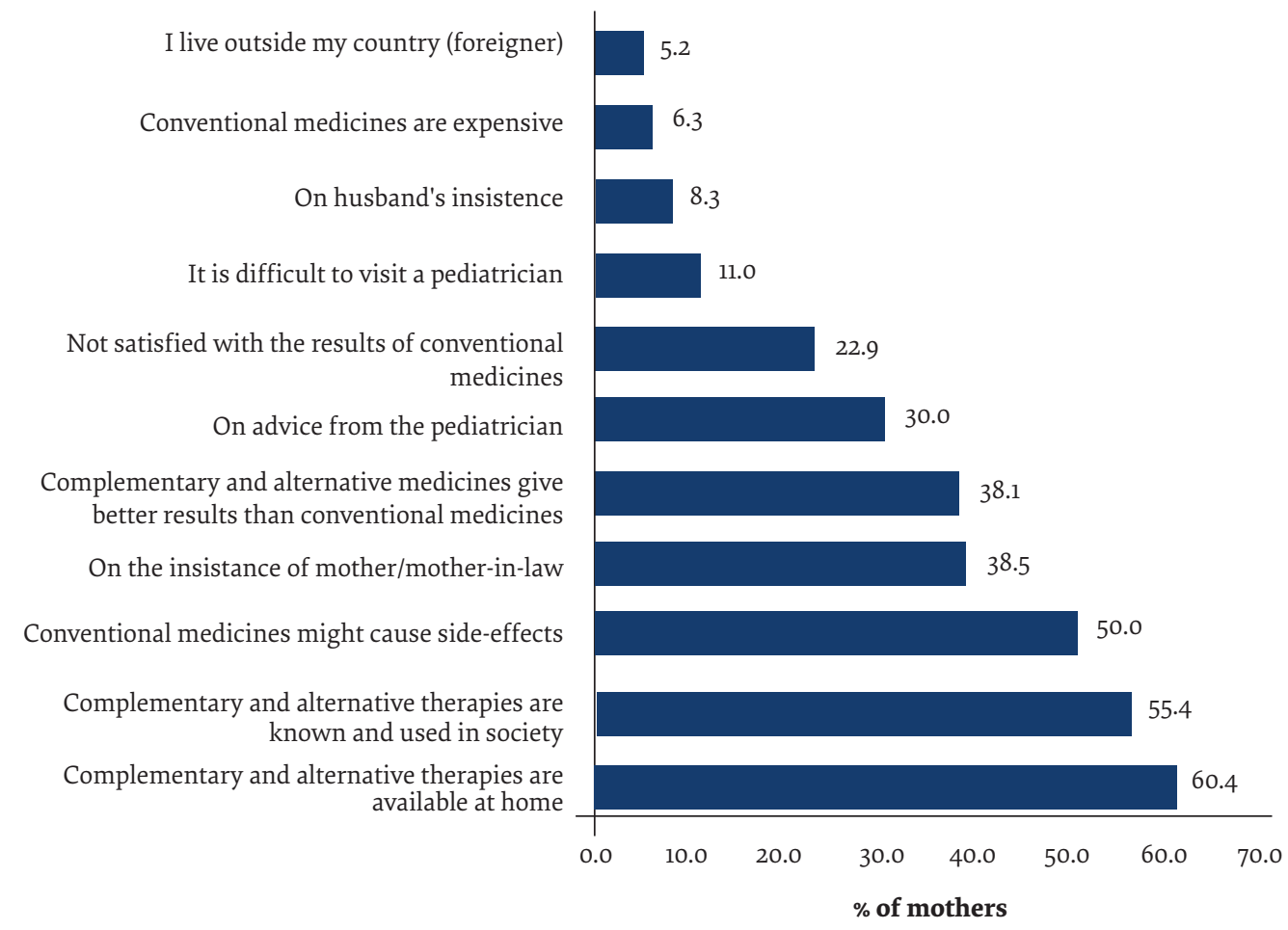

appear to be safe and are recommended as alternatives for treatments (30), it has been reported that Chinese herbal medicine might have side-effects (31). We found that the third most common reason for using complementary and alternative medicine was the fear of side-effects from conventional drugs which concurs with another study (32). Furthermore, parents often choose to give their children natural health products because they believe that these products are safe (33). Most mothers in our study thought that their babies benefited from complementary and alternative medicine, and many said that these medicines gave better results than conventional drugs. Our results show that most of the mothers also used complementary and alternative medicine for themselves. Therefore, we think that awareness campaigns are needed to educate people about the possible side-effects of complementary and alternative medicine and that they should not be preferred to visiting the paediatrician or using conventional drugs.

The findings from our study will help increase the knowledge of parents and of paediatricians, nurses, midwives, pharmacists and health care providers in Jordan who should be well informed about complementary and alternative medicine therapies used in infancy so they can recommend their use or not. Our study has some limitations. Our sample was a convenience sample so may not be representative of all Jordanian mothers. In addition, the questionnaire only reached mothers who were capable of accessing the Internet and social media, and who were members of the Facebook groups where we posted the questionnaire.

Given that mothers' use of complementary and alternative therapies for their infants younger than 3 months is high in Jordan, and that evidence on the safety and efficacy of these products in infants is lacking, we recommend the following: (i) promote awareness of the risks, side-effects and efficacy of the use of both complementary and alternative therapies and conventional medicines in infants; (ii) Educate current and future mothers on dealing with health conditions in infants and the importance of seeking medical information from valid and reliable scientific sources, e.g. doctors, pharmacists and other health care professionals; and (iii) Conduct more research on complementary and alternative therapies to build evidence of their efficacy and possible toxicity so guidelines can be set for their safe and effective use.

\section{Acknowledgement}

We thank the mothers who participated in the study, the administrators of the Facebook groups on which the questionnaire was posted, Dr Rasha Abu-Eid for her contribution in translation, analysis and interpretation of the data, and revising the drafts, and Ms Iman Al-Alami.

Funding: None.

Competing interests: None declared. 


\section{Utilisation de traitements complémentaires et alternatifs chez les nourrissons de moins de trois mois en Jordanie}

\section{Résumé}

Contexte : L'utilisation de médicaments complémentaires et alternatifs chez les nourrissons pour maintenir leur santé et traiter les maladies est populaire en Jordanie. Aucune directive ou réglementation ne régit leur utilisation.

Objectifs : La présente étude a analysé les connaissances des mères et leur recours aux traitements complémentaires et alternatifs chez les nourrissons de moins de trois mois en Jordanie, ainsi que les raisons pour lesquelles elles utilisent ces remèdes.

Méthodes : Il s'agissait d'une étude transversale portant sur un échantillon de commodité de mères de bébés nés en 2015 en Jordanie. Les données ont été recueillies à l'aide d'un questionnaire publié sur six groupes Facebook ciblant les mères en Jordanie. Les mères ont été interrogées sur leur utilisation de plusieurs traitements complémentaires et alternatifs pour différentes affections.

Résultats : Sur les 1028 questionnaires reçus, 520 ont été inclus dans l'analyse. La plupart des mères (81,3\%) étaient âgées de 18 à 29 ans et détenaient un diplôme universitaire (78,3\%). Beaucoup d'entre elles connaissaient l'utilisation des médicaments complémentaires et alternatifs pour le traitement des ballonnements/coliques mais ne les avaient jamais utilisés. Parmi les médicaments utilisés pour le traitement des ballonnements/coliques, l'anis était le plus souvent utilisé (par 70,2 \% des mères). L'anis était également utilisé par 60,8 \% des mères pour aider leur bébé à dormir et par $48,1 \%$ pour la constipation. Les principales raisons de l'utilisation de ces remèdes sont la disponibilité à domicile (60,4 \%) et l'acceptabilité sociale de leur utilisation (55,4\%). Les principales sources d'information sur ces médicaments étaient les femmes plus âgées membres de la famille (78,1\%) et les médias sociaux (56,0\%).

Conclusions: L'utilisation de médicaments complémentaires et alternatifs chez les nourrissons est courante en Jordanie. Des efforts doivent être déployés pour sensibiliser les mères aux risques, aux effets secondaires et à l'efficacité des traitements complémentaires et alternatifs chez les nourrissons.

$$
\begin{aligned}
& \text { استخدام العلاجات التكميلية والبديلة للرضع الأقل من } 3 \text { أشهر في الأردن } \\
& \text { زينة العلمي، إسراء طيبة، ميرفت الصوص، مي أبو حاكمة } \\
& \text { الخالاصة } \\
& \text { الخلفية: يحظى استخدام الطب التكميلي و البديل مع الرََّّّّع بغرض الحفاظ على الصحة وعلاج الأمراض بشعبية في الأردن، غير أنه لا تو جد مبادئ } \\
& \text { توجيهية أو لوائح تحكم استخدامه. }
\end{aligned}
$$

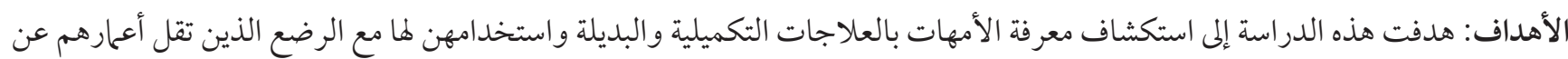

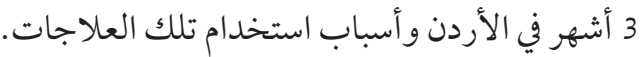

$$
\begin{aligned}
& \text { طرق البحث: هذه در اسة مقطعية لعينة عشو ائية من أمهات الأطفال الذين وُلدوا في عام } 15 \text { عال } 20 \text { في الأردن. وُجمعت البيانات باستخدام استبيان نُشر }
\end{aligned}
$$

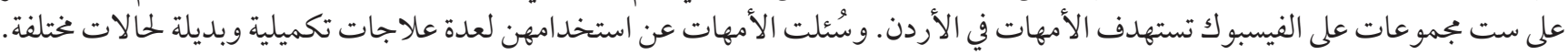

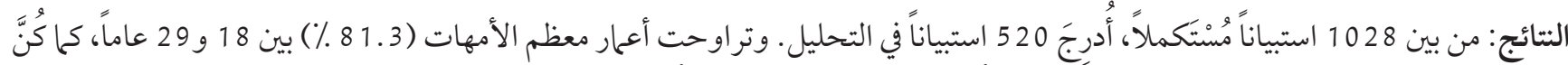

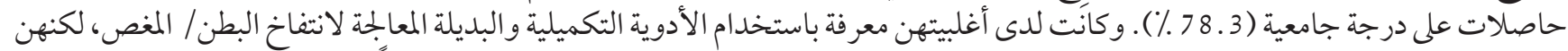

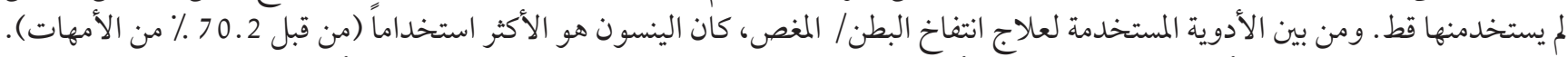

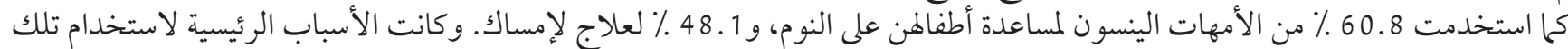

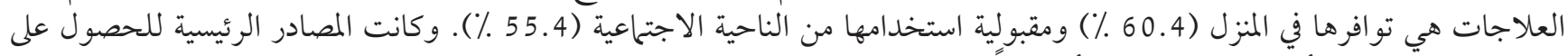

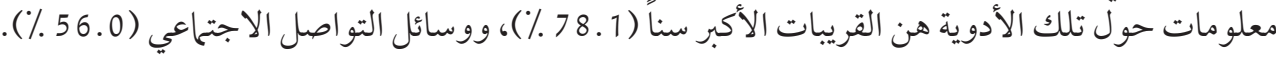

$$
\begin{aligned}
& \text { الاستنتاجات: يشيع استخدام الأدوية التكميلية والبديلة للرضع في الأردن. ويلزم بذل جهود لإذكاء وعي الأمهات بمخاطر العلاجات التكميلية }
\end{aligned}
$$

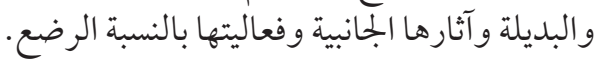




\section{References}

1. Abu-Baker NN, Savage C, Amarneh BH. Parents' strategies of managing minor childhood illnesses using complementary and alternative medicine in Jordan. Global J Health Sci. 2018;10(2):145-54. https://doi.org/10.5539/gjhs.v1on2p145

2. Traditional, complementary and integrative medicine. Definitions [Internet]. World Health Organization (https://www.who.int/ traditional-complementary-integrative-medicine/about/en/, assessed 27 May 2020).

3. Zuzak TJ, Boňková J, Careddu D, Garami M, Hadjipanayis A, Jazbec J, et al. Use of complementary and alternative medicine by children in Europe: published data and expert perspectives. Complement Ther Med. 2013;21(Suppl 1):S34-47. https://doi. org/10.1016/j.ctim.2012.01.001

4. Harris PE, Cooper KL, Relton C, Thomas KJ. Prevalence of complementary and alternative medicine (CAM) use by the general population: a systematic review and update. Int J Clin Pract. 2012;66(10):924-39. https://doi.org/10.1111/j.1742-1241.2012.02945.X

5. Ricklefs I, Hohmann-Ebbers M, Herz A, Kopp MV. Use of complementary and alternative medicine in children with asthma. Pediatr Allergy Immunol. 2018;29(3):326-8. https://doi.org/10.1111/pai.12863

6. Doering JH, Reuner G, Kadish NE, Pietz J, Schubert-Bast S. Pattern and predictors of complementary and alternative medicine (CAM) use among pediatric patients with epilepsy. Epilepsy Behav. 2013;29(1):41-6. https://doi.org/10.1016/j.yebeh.2013.06.025

7. Searight HR, Robertson K, Smith T, Perkins S, Searight BK. Complementary and alternative therapies for pediatric attention deficit hyperactivity disorder: a descriptive review. ISRN Psychiatry. 2012;2012:804127. https://doi.org/10.5402/2012/804127

8. Levy SE, Hyman SL. Complementary and alternative medicine treatments for children with autism spectrum disorders. Child Adolesc Psychiatr Clin N Am. 2015;24(1):117-43. https://doi.org/10.1016/j.chc.2014.09.004

9. Chin EM, Gwynn HE, Robinson S, Hoon AH Jr. Principles of medical and surgical treatment of cerebral palsy. Neurol Clin. 2020;38(2):397-416. https://doi.org/10.1016/j.ncl.2020.01.009

10. Grossoehme DH, Cotton S, McPhail G. Use and sanctification of complementary and alternative medicine by parents of children with cystic fibrosis. J Health Care Chaplain. 2013;19(1):22-32. https://doi.org/10.1080/08854726.2013.761007

11. Serpico MR, Boyle BM, Kemper KJ, Kim SC. Complementary and alternative medicine use in children with inflammatory bowel diseases: a single-center survey. J Pediatr Gastroenterol Nutr. 2016;63(6):651-7. https://doi.org/10.1097/MPG.0000000000001187

12. Nousiainen P, Merras-Salmio L, Aalto K, Kolho KL. Complementary and alternative medicine use in adolescents with inflammatory bowel disease and juvenile idiopathic arthritis. BMC Complement Altern Med. 2014;14:124. https://doi.org/10.1186/1472-688214-124

13. Polevoy T. Complementary medicine: risks to infants and children. J Clin Med. 2018;7(6):149. https://doi.org/10.3390/jcm7060149

14. Porcino A, Solomonian L, Zylich S, Gluvic B, Doucet C, Vohra S. Pediatric training and practice of Canadian chiropractic and naturopathic doctors: a 2004-2014 comparative study. BMC Complement Altern Med. 2017;17(1):512. https://doi.org/10.1186/s12906017-2024-5

15. Aburahma SK, Khader YS, Alzoubi K, Sawalha N. Complementary and alternative medicine use in a pediatric neurology clinic. Complement Ther Clin Pract. 2010;16(3):117-20. https://doi.org/10.1016/j.ctcp.2010.02.005

16. Albashtawy M, Gharaibeh H, Alhalaiqa F, Batiha A-M, Freij M, Saifan A, et al. The health belief model's impacts on the use of complementary and alternative medicine by parents or guardians of children with cancer. Iran J Public Health. 2016;45(5):708-9.

17. Al-Qudimat MR, Rozmus CL, Farhan N. Family strategies for managing childhood cancer: using complementary and alternative medicine in Jordan. J Adv Nurs. 2011;67(3):591-7. https://doi.org/10.1111/j.1365-2648.2010.05517.x

18. Mrayan L, Abujilban S, Abuidhail J, Alshraifeen A. Traditional neonatal care practices in Jordan: a qualitative study. Nurs Health Sci. 2018;20(4):486-93. https://doi.org/10.1111/nhs.12540

19. Al-Sagarat AY, Al-Kharabsheh A. Traditional practices adopted by Jordanian mothers when caring for their infants in rural areas. Afr J Tradit Complement Altern Med. 2016;14(1):1-9. https://doi.org/10.21010/ajtcam.v14i1.4499

20. Registered live births by sex and governorate [Internet]. Amman: Department of Statistics; 2015 (http://dosweb.dos.gov.jo/ar/population/births-and-deaths/tables-birthsdeaths/, accessed 8 September 2019).

21. Sarasu JM, Narang M, Shah D. Infantile colic: an update. Indian Pediatr. 2018;55(11):979-87.

22. Javan R, Feyzabadi Z, Kiani MA. Management of infantile colic; based on traditional Iranian medicine. Int J Pediatr. 2015;3(5):909-13.

23. Alachkar A, Jaddouh A, Elsheikh MS, Bilia AR, Vincieri FF. Traditional medicine in Syria: folk medicine in Aleppo governorate. Nat Prod Commun. 2011;6(1):79-84.

24. Shojaii A, Abdollahi Fard M. Review of pharmacological properties and chemical constituents of Pimpinella anisum. ISRN Pharm. 2012;2012:510795. https://doi.org/10.5402/2012/510795

25. Casanova Cuenca M, Calzado Agrasot MÁ, Mir Pegueroles C, Esteban Cantó V. New cases of star anise poisoning: are we providing enough information? Neurologia. 2019;34(3):211-3. https://doi.org/10.1016/j.nrl.2017.05.006

26. de Groot AC, Schmidt E. Essential Oils, Part III: Chemical Composition. Dermatitis. 2016;27(4):161-9. https://doi.org/10.1097/ DER.0000000000000193

27. Arab reading index 2016. United Arab Emirates: Mohammed Bin Rashid Al Maktoum Foundation and United Nations Develop- 
ment Programme; 2016 (https://knowledge4all.com/admin/uploads/files/ARI2016/ARI2016En.pdf, accessed 18 May 2020).

28. Telecommunication Regulatory Commission. Annual report 2016. Amman: Telecommunication Regulatory Commission; 2016:50-1.

29. Wazaify M, Alawwa I, Yasein N, Al-Saleh A, Afifi FU. Complementary and alternative medicine (CAM) use among Jordanian patients with chronic diseases. Complement Ther Clin Pract. 2013;19(3):153-7. https://doi.org/10.1016/j.ctcp.2013.03.001

30. Ventegodt S, Merrick J. A review of side-effects and adverse events of non-drug medicine (nonpharmaceutical complementary and alternative medicine): psychotherapy, mind-body medicine and clinical holistic medicine. J Complement Integr Med. 2009;6(1). https://doi.org/10.2202/1553-3840.1156

31. Wong HC. Side-effects of CAM/Chinese herbal meds. Br Columbia Med J. 2008;50(2):58.

32. Beer AM, Burlaka I, Buskin S, Kamenov B, Pettenazzo A, Popova D, et al. Usage and attitudes towards natural remedies and homeopathy in general pediatrics: a cross-country overview. Glob Pediatr Health. 2016;3:2333794X15625409. https://doi. org/10.1177/2333794X15625409

33. Pike A, Etchegary H, Godwin M, McCrate F, Crellin J, Mathews M, et al. Use of natural health products in children: qualitative analysis of parents' experiences. Can Fam Physician. 2013;59(8):e372-8. 